\title{
ACCUMULATED THERMAL TIME AFFECTS GROWTH, YIELD AND PHENOLOGICAL DEVELOPMENT OF SESAME (Sesamum indicum L.) IN THE DRY ZONE OF SRI LANKA
}

\author{
Kumara $\mathrm{HWKP}^{1 *}$, Fernando $\mathrm{KMC}^{2}$ and Gunathilaka WMND ${ }^{3}$ \\ ${ }^{1}$ Faculty of Graduate Studies, University of Ruhuna, Matara, Sri Lanka \\ ${ }^{2}$ Department of Crop Science, Faculty of Agriculture, University of Ruhuna, Mapalana, \\ Kamburupitiya, Sri Lanka \\ ${ }^{3}$ Agriculture Research Station, Department of Agriculture, Labuduwa, Galle, Sri Lanka \\ Received: 11 May 2021: Accepted: 04 November 2021
}

\begin{abstract}
The present experiment was conducted to determine the impact of accumulated thermal time on the growth, yield and phenology of Sesame (Sesamum indicum L.) in the dry zone of Sri Lanka. Uma, Malee and MI-3 varieties were selected and the seeds were sown on three different dates in the 2016 Yala and 2016/2017 Maha seasons. The experiment was set up according to a two-factor factorial randomized completely block design with three replicates. Accumulated thermal time was calculated as growing degree days at the vegetative stage, flowering initiation, $\mathbf{5 0 \%}$ of flowering, $\mathbf{1 0 0 \%}$ of flowering and physiological maturity using minimum and maximum daily temperature. Then the plant height and the number of leaves per plant were plotted against the accumulated thermal time using the sigmoid growth model. The seed dry weight and dry weight of 1000 seeds were recorded at maturity. The relationship of plant height and the number of leaves per plant with accumulated growing degree days (AGDD) was significant for all varieties at different sowing dates in both seasons. The flowering of sesame initiated at 741 and 713.1 of AGDD in Yala and Maha seasons, respectively. The AGDD needed for $50 \%$ flowering in the Yala is greater than the Maha season. Full flowering occurred in Maha earlier than the Yala season. Plants reached physiological maturity early in the Maha season. Seed weight per 15 plants and seed weight per plot were significantly affected by the interaction between variety and the sowing date in Maha and Yala seasons, respectively. The highest seed weight per 15 plants was recorded in var. Uma and var. Malee in Yala season while the highest seed weight per plot was also recorded by var. Uma. Furthermore, 1000 seed weight was greater in var. Uma than other varieties in both seasons. Sowing seeds early in the season increased seed weight per 15 plants in Yala while seeds per plot and 1000 seed weight in Maha season. According to the results of the present study, var. Uma could be considered as an efficient sesame variety that performed better when sown early in the season. Therefore, cultivating var. Uma, early in the seasons might be beneficial in terms of growth and yield in the dry zone of Sri Lanka. However, further field studies are needed to give a solid recommendation.
\end{abstract}

Keywords: Accumulated thermal time, Maha season, Phenology, Sesamum indicum, Yala season

\section{INTRODUCTION}

Plants need a certain amount of heat for development and shift from one phonological phase to another phase. Farmers take some important management decisions by considering the number of calendar dates more often. However, it is erroneous of using calendar dates, especially in the early crop growth, since temperature changes would

Corresponding author: hwkpkumara@gmail.com affect the duration of some growth stages (Dubey et al. 2018; Hatfield and Prueger 2015; Miller et al. 2001). Therefore, the ability to predict a specific crop stage would allow taking better management decisions such as fertiliser application and predicting vegetative phase relatively to insect and weed life cycles (Ahmad et al. 2017). Sesame cultivation requires a different number of days for growth and development. Different 
planting dates create different sets of environmental conditions, from seedling emergence to physiological maturity (Mulkey et al. 1987). Temperature is the driving force behind all biological activities. As a result, the growth, development and reproduction of many organisms are predictable by different heat parameters. Heat value of each day is measured as thermal time and indicated by growing degree days (GDD) (Danneberger and Cushnahan 2014). Thermal time requirement for a given crop is calculated as sum of the growing degree days throughout the growing season. The resulting "thermal time" more consistently predicts when a certain plant stage will occur (Anandhi 2016). Growing degree days are often used as a climate-based indicator to assess crop phenology (Anandhi 2016). The degrees of growth day is used to assess the suitability of a region for the production of a given crop, determine the growth stages of crops, assess the optimum times for the application of fertilizers and herbicides, estimate the accumulation of stress of temperature, predict physiological maturity and harvest dates and use as the ideal meteorological unit in constructing crop models (Parthasarathi et al. 2013).

The GDD could be the best tool to predict the phenology of the most of annual plants (Miller et al. 2001). Therefore, several GDD predicting models were developed in several countries to explain the future of the growth and development of the cultivations. They had observed increment of GDD with time when simulation of the models (Anandhi 2016; Lalic et al. 2016; Paparrizos and Matzarakis 2017). Furthermore, several experiments were conducted by using temperature data for long periods in several countries around the world aiming to find out the impact of climatic change on growing degree days (GDD). They have found that there are offset of GDD with time (Hassan 2007; Bekere et al. 2015; Yin et al. 2019). The GDD increased due to global warming and that have being focusing matter in agriculture sector due to direct impact of GDD on cultivations (Bekere et al. 2015; Yin et al. 2019).
Sesame (Sesamum indicum L.) belongs to the family of Pedaliaceae, a seasonal and shortday plant having four major phonological phases as vegetative, reproductive, ripening and drying (Langham 2016). Sesame is a drought-tolerant plant and growing mainly in the tropical and subtropical regions of the world, although it can be grown in temperate climates (Hegde 2012; Ashri 1998). Daytime temperatures for optimal growth of sesame should be ranged between $25^{\circ} \mathrm{C}$ and $27^{\circ} \mathrm{C}$ (Hegde 2012; Langham 2007; Oplinger et al. 1990). Sesame is a short day plant with the 10 hours per day of optimal photoperiod (Hegde 2012; Langham 2007) and normally cultivates as a low altitude crop which are growing below $1250 \mathrm{~m}$. However, it can be cultivated in areas with high altitudes in Nepal and India. Sesame plants in high altitude are relatively small in size and unbranched with low seed yield while the length of the life cycle is also short (Hegde 2012). Though $S$. indicum typically requires rather warm conditions for optimal growth and yield (Bahrami et al. 2012), the abnormally high temperature during sesame flowering may lose of flowers, loss of pollen sterility and lead to premature yields (Kumazaki et al. 2008). Sesame is a drought-tolerant crop but requires sufficient moisture for germination and early growth. Therefore, rainfall in between $500 \mathrm{~mm}$ to $650 \mathrm{~mm}$ is needed. However, sesame is intolerant to water logging conditions (Oplinger et al. 1990). Sesame has been used as a condiment flavour agent and traditional medicine in Sri Lanka. It is mainly cultivated on a small scale and the production is slightly more than $1 \mathrm{t}$ ha- 1 . Land extent for sesame cultivation in Sri Lanka is around 6,035 ha in 2019 while the total annual production is $6,085 \mathrm{t}$. The Anuradhapura district contributed the highest, 1904 ha, to the total land extent (AgStat 2020). Further, the land extent of Sesame cultivation in Yala season is greater than Maha season. It is cultivated as a secondary crop in Yala season and as a primary crop grown during Maha season (Dissanayake et al. 2017). Sesame could give reasonable yield under dry conditions with over high temperature and limited soil moisture due to low rainfall (Bahrami et al. 2012). Temperature is a 
crucial abiotic factor that influences growth and development of sesame.

Sri Lanka is an agricultural country with twothird of its total land area belonging to the dry zone that experiences less than $1750 \mathrm{~mm}$ of annual precipitation with a dry period in May to September. According to the Center for Socio-Economic Planning, 14 out of 19 districts cultivate sesame belonged to dry zone in 2019 (AgStat 2020). The current study was carried out to determine the necessary demand of growing degree days for different phenological stages of selected sesame varieties while investigating the effect of growing degree days on sesame growth and yield in the dry zone of Sri Lanka.

\section{MATERIALS AND METHODS}

\section{Experiment site and treatments}

The present experiment was conducted in the fields of Grain Legumes and Oil Crops Research and Development Center, Angunakolapelessa located in Hambantota district of southern province, Sri Lanka. In this area, rolling and undulating land patterns could be identified with Red Brown Earth and Low Humic Gray soils. Angunakolapelessa belongs to low country dry zone and in agroecological region DL1b (Natural Resource Management Center, 2003). Three commercial varieties (var. Uma, Malee and MI-3) were cultivated at three different sowing dates (early, mid and late of the particular season) in 2016 Yala and 2016/2017 Maha seasons (hereafter Yala \& Maha). The Maha season falls during Northeast monsoon from September to March while the effective period of Yala season is May to September parallel to Southwest monsoon in Sri Lanka. The size of the plot was $4 \mathrm{~m} \times 3 \mathrm{~m}$ and the spacing of planting was $30 \mathrm{~cm} \times 20 \mathrm{~cm}$. The experiment was set up according to two-factor factorial randomized completely block design with three replicates. Factor one was the variety while factor two was the sowing date. Table 1 shows the details of different treatment combinations applied in the experiment for both seasons. The experiment was carried out for 16 weeks in each season.

\section{Measured parameters}

Accumulated thermal time as growing degree days $\left(\mathrm{GDD},{ }^{\circ} \mathrm{Cd}\right)$ was calculated throughout the experiment in two weeks intervals. The mean day temperature was calculated by dividing the sum of maximum and minimum temperature for the day by two. Then, the thermal time was calculated by subtracting the base temperature from the mean day temperature. After that accumulated thermal time was calculated by summing up the thermal time of a particular period as accumulated growing degree days (AGDD) (Equation 1). Accordingly, AGDD at relevant different growth stages; vegetative phase, flowering initiation, $50 \%$ flowering, $100 \%$ flowering and physiological maturity were

Table 1: Treatment combinations of the experiment conducted in Yala season 2016 and Maha season 2016/2017

\begin{tabular}{llrlr}
\hline $\begin{array}{l}\text { Treatment } \\
\text { combinations }\end{array}$ & \multicolumn{2}{c}{ Yala Season 2016 } & \multicolumn{2}{c}{ Maha Season 2016/2017 } \\
\cline { 2 - 5 } & $\begin{array}{l}\text { Factor 1 } \\
\text { (Variety }\end{array}$ & $\begin{array}{c}\text { Factor 2 } \\
\text { (Sowing date) }\end{array}$ & $\begin{array}{l}\text { Factor 1 } \\
\text { (Variety) }\end{array}$ & $\begin{array}{c}\text { Factor 2 } \\
\text { (Sowing date) }\end{array}$ \\
\hline T1 & Uma & 07 April 2016 & Uma & 21 October 2016 \\
T2 & Uma & 21 April 2016 & Uma & 04 November 2016 \\
T3 & Uma & 05 May 2016 & Uma & 18 November 2016 \\
T4 & Malee & 07 April 2016 & Malee & 21 October 2016 \\
T5 & Malee & 21 April 2016 & Malee & 04 November 2016 \\
T6 & Malee & 05 May 2016 & Malee & 18 November 2016 \\
T7 & MI-3 & 07 April 2016 & MI-3 & 21 October 2016 \\
T8 & MI-3 & 21 April 2016 & MI-3 & 04 November 2016 \\
T9 & MI-3 & 05 May 2016 & MI-3 & 18 November 2016 \\
\hline
\end{tabular}


identified based on the sowing dates. Fifteen plants were randomly selected to measure the plant height $(\mathrm{cm})$ and the number of leaves per plant at different growth phases mentioned manually. Seed weight of 15 plants $(\mathrm{g})$, seed weight of the plot (g) and 1000 seed weight (TSW; g) were measured during harvesting.

$$
\text { AGDD }=\sum_{\text {Dayi }}^{\text {Dayj }}\left\{\frac{\mathrm{T}_{\max }+\mathrm{T}_{\min }}{2}-\mathrm{T}_{\text {base }}\right\} \ldots \text { Eqn. } 1
$$

Where;

$T_{\max }=$ Maximum daily temperature, $T_{\min }=$ Minimum daily temperature, $T_{\text {base }}=$ Base temperature $\left(10^{\circ} \mathrm{C}\right), i / j=1,2 \ldots$

Then, the plant height and the number of leaves per plant were plotted against the accumulated thermal time using sigmoid growth model (non-linear relationship) (Equation 2) (Meena and Rao 2013).

$$
y=\frac{a}{\left(1+\exp \left(\frac{-\left(\mathrm{x}-\mathrm{x}_{0}\right)}{\mathrm{b}}\right)\right)} \ldots \text { Eqn. } 2
$$

Where;

$Y=$ Growth parameter (plant height or number of leaves), $x=$ accumulated Thermal time (Growing degree days; ${ }^{\circ} C d$ ), $\mathrm{x}_{0}, a$ and $b$ $=$ parameters of sigmoid growth model

\section{Statistical analysis}

Treatment effect on plant growth and yield were tested according to the analysis of variance. Relationship between growing degree days and plant growth parameters was analyzed by non- linear regression procedure. SAS university edition was used to analyze the data.

\section{RESULTS AND DISCUSSION Meteorological data of the experimental site}

Meteorological data during the Yala season and Maha season were obtained from weather station at Grain Legumes and Oil Crops Research and Development center at Angunakolapelessa. Figure 1 (A) shows the maximum temperature, minimum temperature and average daily rainfall of the study area three months period from seed sowing to harvesting. The maximum temperature was significantly high in the Yala season than in the Maha season. The gap between maximum temperature in two seasons in the beginning and the end of the growing season is greater than the middle of the season. The average minimum temperature throughout the Yala season was greater than the Maha season (Fig. 1B). Maha season received high rainfall compared to the Yala season. However, the greater rainfall received in the 4th week to the 6 th week of the Yala season. The early and later phases of the Maha season had received more rainfall than the middle phase (Fig. 1C).

Length of growth and development of sesame may depend on climatic factors such as growing degree days, temperature, rainfall and relative humidity. Soil parameters such as soil type, soil moisture content and fertility and management practices such as spacing are also affected on the growth and development. Langham (2016) reported that the germination period increased with high soil moisture content. Therefore planting time is very critical. The growth of the plant and yield may be affected by planting time (Mulkey et al. 1987). According to Langham (2007), seed germination would be enhanced by soil temperature. Further, it is explained that vegetative and reproductive stages could be lengthened by increasing Growing degree days. When night temperature drops significantly, the time spent for ripening and full maturity may increase (Langham 2016).

\section{Plant height and number of leaves per plant}

The relationship of plant height (Fig. 2, 3 and 4) and the number of leaves per plant (Table 2) with accumulated growing degree days (AGDD) was significant for all varieties at different sowing dates in both seasons. Therefore, height and the number of leaves per plant were significantly affected by AGDD. Results of the previous studies were in line with the findings of the present study (Pandey and Paul 2017; Gloaguen et al. 2018). Meena and Rao (2013) suggested that 
A

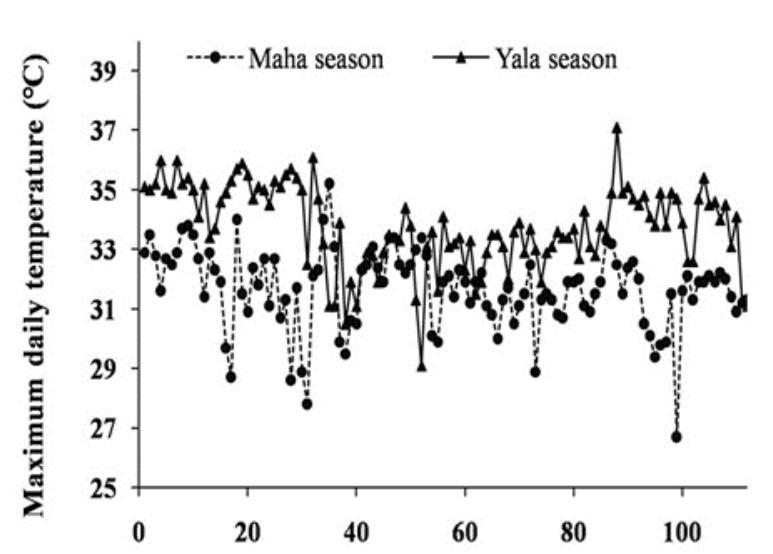

Days after seed sowing
B

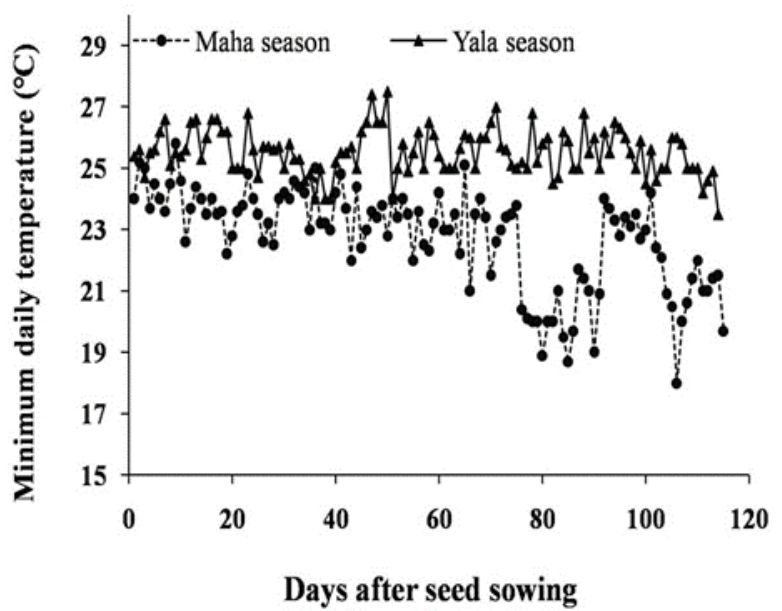

C

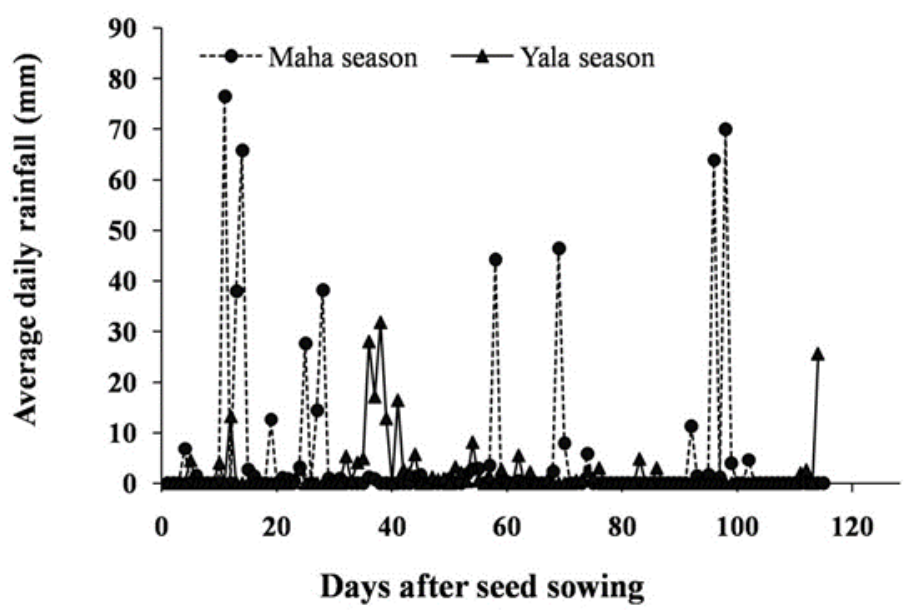

Figure 1: (A) Maximum daily temperature, (B) Minimum daily temperature and (C) average daily rainfall of the study area for 2016 Yala season and 2016/2017 Maha season against the days after seed sowing

AGDD is more important for plant growth than the number of days after seed sowing. Further, the results of the present study showed that selected growth parameters could be predicted by growing degree days and it would be the most accurate method to predict growth parameters (Dutta et al. 2011; Basu et al. 2012). It would be useful when taking agronomical decisions including the identification of planting season and the date (Langham 2007; Meena and Rao 2013).

\section{Phenological development}

Table 3 shows the accumulated thermal time (AGDD) of different treatments at both seasons. According to that, var. Uma needed the lowest AGDD values to end the seedling stage in both seasons. When seeds sown early in the season, plants shift from the seedling stage to the next growth stage faster than the late sowing dates for all varieties in both seasons. However, relatively less AGDD was required for all varieties to reach the vegetative stage in Maha season at all sowing dates. In general, the vegetative stage was lengthened than usual in both seasons.

According to Table 4, the flowering of Uma was initiated by relatively low AGDD than other varieties in both seasons. Furthermore, the time taken for shifting from one growth stage to another stage was much quicker when seeds were sown in early date in both seasons. The vegetative phase would be over when $50 \%$ of plants initiated the flowering while the reproductive phase started. Table 4 shows the GDD from seed sowing to $50 \%$ flowering for different treatments. The lowest AGDD was 
A
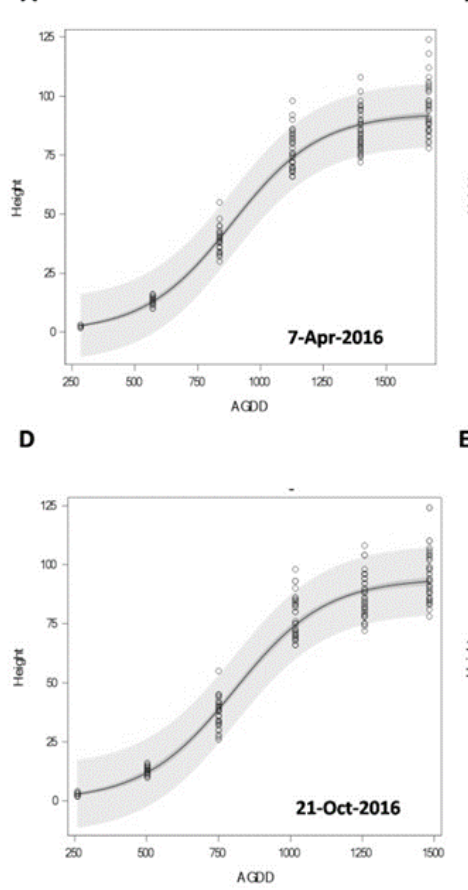

B
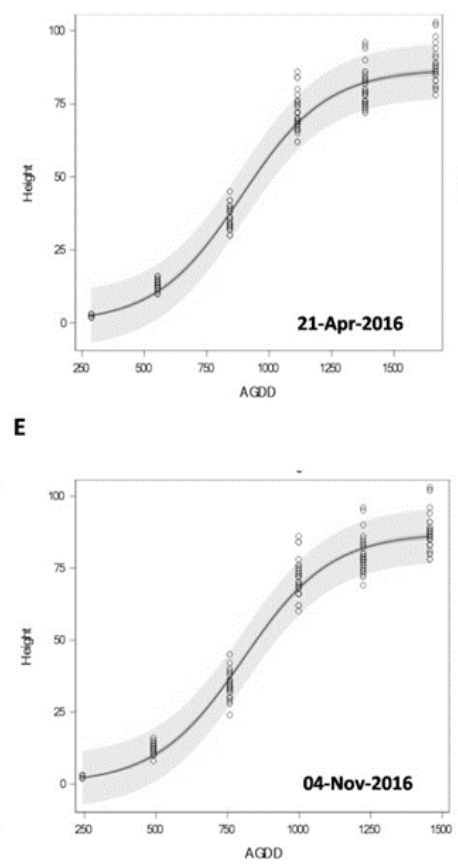

C
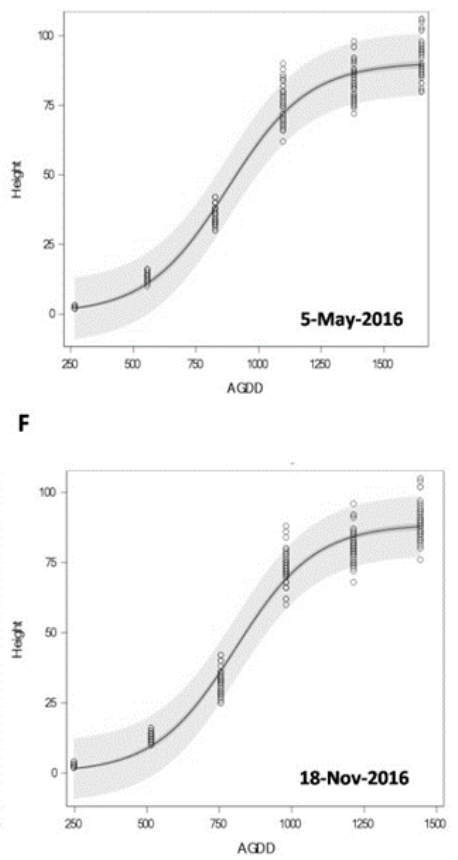

Figure 2: Observed values and fitted curves for plant height of variety Uma against accumulated thermal time $\left({ }^{\circ} \mathrm{Cd}\right)$ for different sowing dates in Yala/Maha seasons $(\mathrm{A}) 7^{\text {th }}$ April 2016 (B) $21^{\text {st }}$ April 2016 (C) $5^{\text {th }}$ May 2016 (D) $21^{\text {st }}$ October 2016 (E) $4^{\text {th }}$ November 2016 and $(F) 18^{\text {th }}$ November 2016.

Table 2: Estimated parameters of sigmoid growth model for number of leaves per plant of three varieties (Uma, Malee and MI-3) in three sowing dates in Yala (07 April 2016, 21 April 2016 and 05 May 2016) and Maha (21 October 2016, 04 November 2016 and 18 November 2016) seasons

\begin{tabular}{|c|c|c|c|c|c|c|c|}
\hline \multirow{2}{*}{ Season } & \multirow{2}{*}{ Sowing Date } & \multirow{2}{*}{ Variety } & \multicolumn{3}{|c|}{ Parameters } & \multirow[t]{2}{*}{ F value } & \multirow[t]{2}{*}{$P$ value } \\
\hline & & & $a$ & $\mathrm{~b}$ & $\mathrm{X}_{0}$ & & \\
\hline \multirow{9}{*}{$\begin{array}{l}\text { Yala } \\
\text { Season }\end{array}$} & \multirow{3}{*}{07 April 2016} & Uma & 46.63 & 263.71 & 1004.54 & 9042.36 & $<0.001$ \\
\hline & & Malee & 40.14 & 247.34 & 971.92 & 9146.15 & $<0.001$ \\
\hline & & MI-3 & 38.07 & 232.40 & 936.37 & 7578.86 & $<0.001$ \\
\hline & \multirow{3}{*}{21 April 2016} & Uma & 47.72 & 299.91 & 1082.65 & 6783.52 & $<0.001$ \\
\hline & & Malee & 39.28 & 266.17 & 1004.43 & 5767.04 & $<0.001$ \\
\hline & & MI-3 & 37.97 & 239.12 & 966.01 & 9443.04 & $<0.001$ \\
\hline & \multirow{3}{*}{05 May 2016} & Uma & 44.14 & 277.70 & 1053.27 & 12815.20 & $<0.001$ \\
\hline & & Malee & 40.41 & 262.61 & 1020.54 & 10952.50 & $<0.001$ \\
\hline & & MI-3 & 38.76 & 256.90 & 1008.60 & 13673.10 & $<0.001$ \\
\hline \multirow{9}{*}{$\begin{array}{l}\text { Maha } \\
\text { Season }\end{array}$} & \multirow{3}{*}{$\begin{array}{l}21 \text { October } \\
2016\end{array}$} & Uma & 45.00 & 246.22 & 909.32 & 9896.63 & $<0.001$ \\
\hline & & Malee & 40.24 & 227.91 & 876.45 & 8089.98 & $<0.001$ \\
\hline & & MI-3 & 40.53 & 219.95 & 858.23 & 7500.38 & $<0.001$ \\
\hline & \multirow{3}{*}{04 November } & Uma & 46.56 & 256.93 & 953.39 & 6679.68 & $<0.001$ \\
\hline & & Malee & 41.66 & 241.25 & 926.83 & 6265.16 & $<0.001$ \\
\hline & & MI-3 & 39.74 & 227.65 & 893.40 & 7681.97 & $<0.001$ \\
\hline & \multirow{3}{*}{$\begin{array}{l}18 \text { November } \\
2016\end{array}$} & Uma & 43.58 & 237.21 & 948.62 & 10730.40 & $<0.001$ \\
\hline & & Malee & 40.11 & 220.86 & 913.80 & 12639.00 & $<0.001$ \\
\hline & & MI-3 & 40.58 & 223.10 & 916.44 & 10996.70 & $<0.001$ \\
\hline
\end{tabular}


A

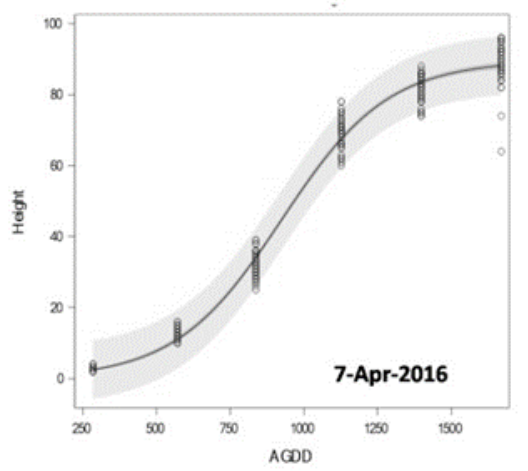

D

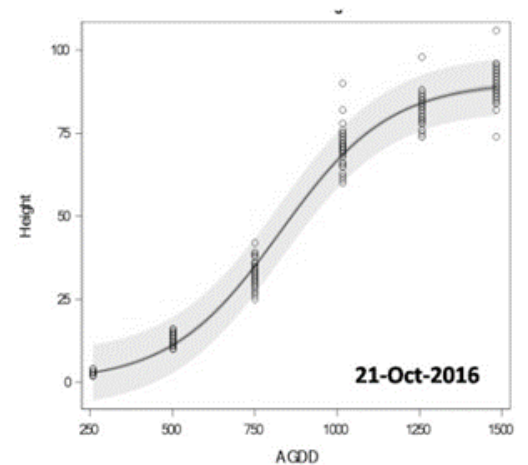

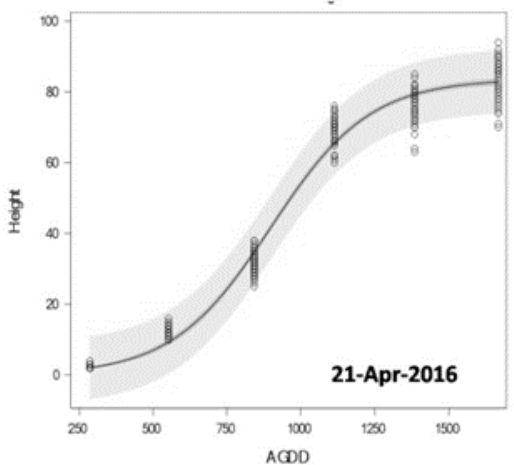

E

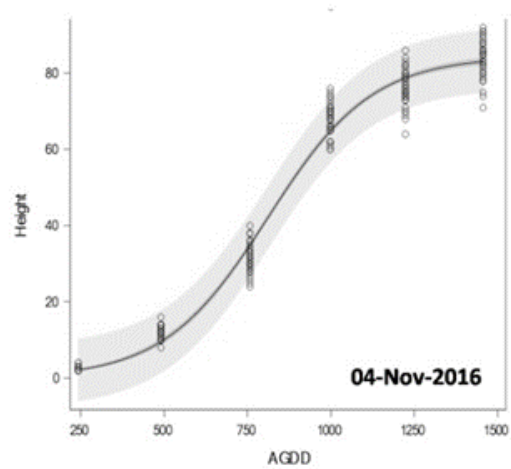

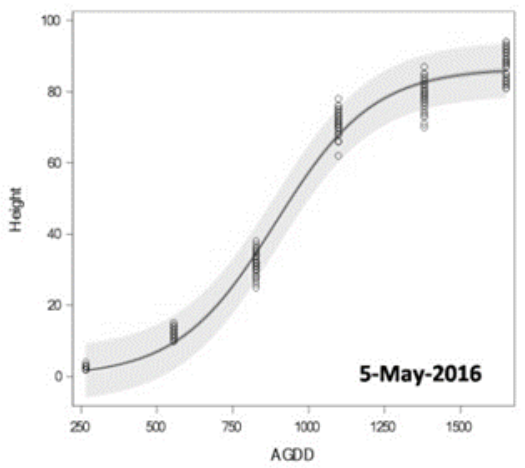

$\mathbf{F}$

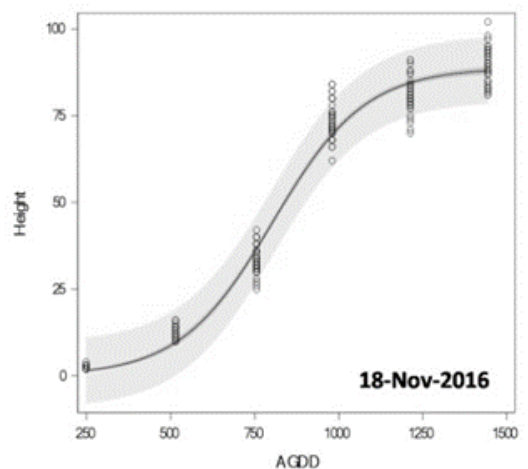

Figure 3: Observed values and fitted curves for plant height of variety Malee against accumulated thermal time $\left({ }^{\circ} \mathrm{Cd}\right)$ for different sowing dates in Yala/Maha seasons (A) $7^{\text {th }}$ April 2016 (B) $21^{\text {st }}$ April 2016 (C) $5^{\text {th }}$ May 2016 (D) $21^{\text {st }}$ October 2016 (E) $4^{\text {th }}$ November 2016 and $(F) 18^{\text {th }}$ November 2016

needed for var. Uma to achieve $50 \%$ of flowering. GDD requirement to move into the next stage is relatively low when seeds were sown early in the season (Table 5).

Around $80 \%$ of flowers opened at the end of the reproductive stage (Langham et al. 2008) and the most productive stage. Flowering and capsule development both would occur on the main stem and branches during this stage.
Therefore, the plants should be strictly protected from stress during this stage. If the moisture is running out, the number of flowers that opens a day will reduce (Langham 2007). Furthermore, the reproductive phase is extended until physical maturity occurred. This phase also consisted of 3 stages and the reproductive phase would be over when $90 \%$ of plants terminate the flowering.

Table 3: Accumulated thermal time as growing degree days (AGDD) from seed sowing to beginning of the vegetative stage of three varieties at three sowing dates in Yala and Maha season. Time taken for reaching to the particular stage is given as number of days after seed sowing (DAS)

\begin{tabular}{lrrrrrrr}
\hline \multirow{2}{*}{ Season } & \multicolumn{2}{c}{ Sowing date } & \multicolumn{2}{c}{ Uma } & \multicolumn{2}{c}{ Malee } & \multicolumn{2}{c}{ MI-3 } \\
\cline { 3 - 8 } & & AGDD & DAS & AGDD & DAS & AGDD & DAS \\
\hline \multirow{3}{*}{ Yala } & 07 April 2016 & 509.50 & 25 & 550.51 & 27 & 550.50 & 27 \\
& 21 April 2016 & 515.70 & 26 & 552.83 & 28 & 572.00 & 29 \\
& 05 May 2016 & 536.50 & 28 & 555.66 & 29 & 575.40 & 30 \\
\hline \multirow{3}{*}{ Maha } & 21 October 2016 & 452.75 & 25 & 486.65 & 27 & 486.65 & 27 \\
& 04 November 2016 & 472.65 & 27 & 508.34 & 29 & 508.30 & 29 \\
& 18 November 2016 & 513.15 & 29 & 530.02 & 30 & 530.00 & 30 \\
\hline
\end{tabular}


A

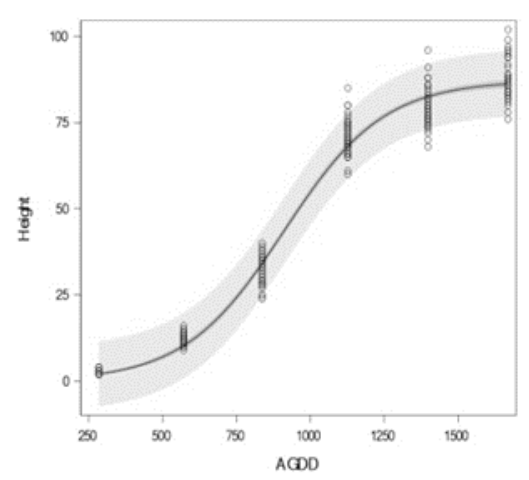

D

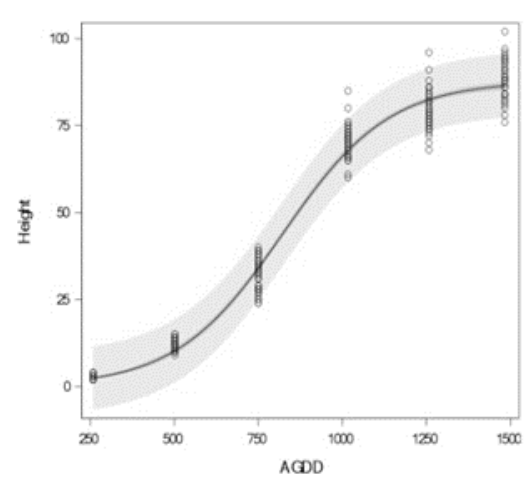

B

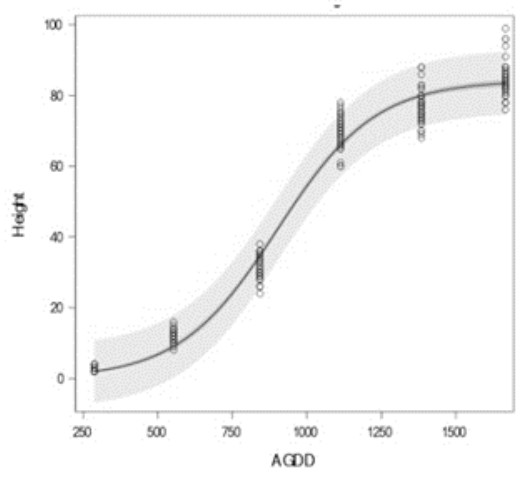

E

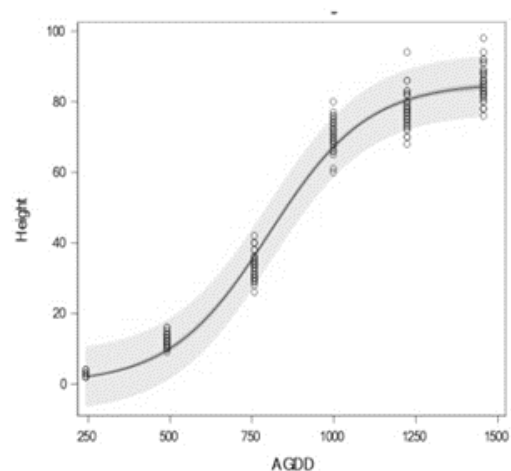

C

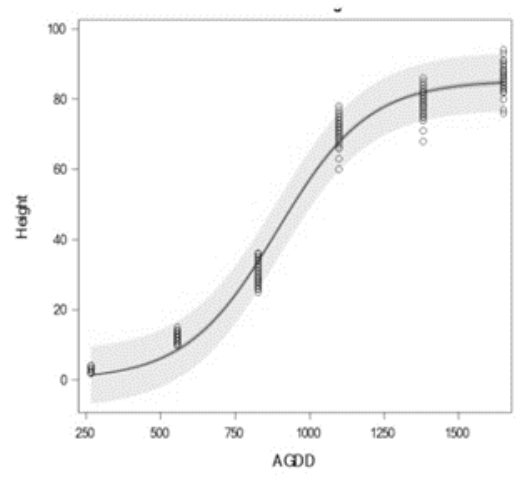

$\mathbf{F}$

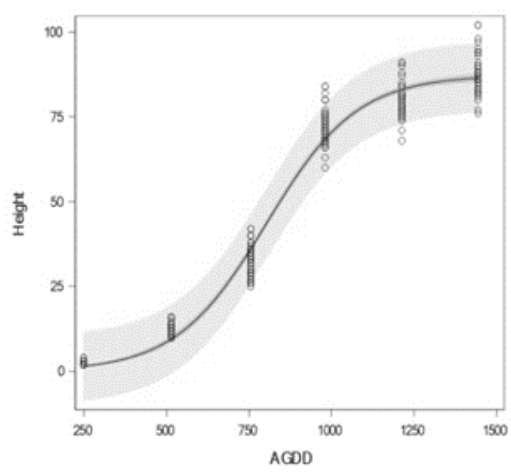

Figure 4: Observed values and fitted curves for plant height of variety MI-3 against accumulated thermal time $\left({ }^{\circ} \mathrm{Cd}\right)$ for different sowing dates in Yala/Maha seasons (A) $7^{\text {th }}$ April 2016 (B) $21^{\text {st }}$ April 2016 (C) $5^{\text {th }}$ May 2016 (D) $21^{\text {st }}$ October 2016 E) $4^{\text {th }}$ November 2016 and $(F) 18^{\text {th }}$ November 2016

In the Yala season, all of the plants of every variety at all sowing dates were completed the flowering at the beginning of the 9th week after seed sowing. Var. Uma recorded the lowest AGDD among varieties in both seasons. Var. Malee and var. MI-3 showed the same intention about AGDD regard to $100 \%$ flowering (Table 6).
Table 7 shows AGDD at physiological maturity of all treatments. Var. Uma was the variety that needed the lowest AGDD to reach physiological maturity. AGDD was not significantly different among sowing dates, but the number of days after sowing was different. AGDD was lower in the Maha

Table 4: Accumulated thermal time as growing degree days (AGDD) from seed sowing to beginning of the flowering of three varieties at three sowing dates in Yala and Maha season

\begin{tabular}{lrrrcccc}
\hline \multirow{2}{*}{ Season } & \multirow{2}{*}{ Sowing Date } & \multicolumn{2}{c}{ Uma } & \multicolumn{2}{c}{ Malee } & \multicolumn{2}{c}{ MI-3 } \\
\cline { 3 - 8 } & & AGDD & DAP & AGDD & DAP & AGDD & DAP \\
\hline \multirow{3}{*}{ Yala } & 07 April 2016 & 726.04 & 36 & 745.41 & 37 & 745.41 & 37 \\
& 21 April 2016 & 730.72 & 37 & 748.38 & 38 & 748.34 & 38 \\
& 05 May 2016 & 728.74 & 38 & 747.74 & 39 & 747.77 & 39 \\
\hline \multirow{3}{*}{ Maha } & 21 October 2016 & 696.21 & 39 & 713.53 & 40 & 713.52 & 40 \\
& 04 November 2016 & 689.55 & 39 & 722.28 & 41 & 722.25 & 41 \\
& 18 November 2016 & 703.63 & 40 & 736.81 & 42 & 720.52 & 41 \\
\hline
\end{tabular}


Table 5: Accumulated thermal time as growing degree days (AGDD) from seed sowing to $50 \%$ of the flowering of three varieties at three sowing dates in Yala and Maha season. Time taken for reaching to the particular stage is given as number of days after seed sowing (DAS)

\begin{tabular}{cccccccc}
\hline \multirow{2}{*}{ Season } & \multirow{2}{*}{ Sowing Date } & \multicolumn{2}{c}{ Uma } & \multicolumn{2}{c}{ Malee } & \multicolumn{2}{c}{ MI-3 } \\
\cline { 2 - 7 } & & AGDD & DAS & AGDD & DAS & AGDD & DAS \\
\hline \multirow{3}{*}{ Yala } & 07 April 2016 & 914.15 & 46 & 954.45 & 48 & 954.45 & 48 \\
& 21 April 2016 & 920.32 & 47 & 957.65 & 49 & 957.65 & 49 \\
& 05 May 2016 & 922.27 & 48 & 961.67 & 50 & 961.67 & 50 \\
\hline \multirow{3}{*}{ Maha } & 21 October 2016 & 893.55 & 50 & 912.05 & 51 & 912.05 & 51 \\
& 04 November 2016 & 896.92 & 51 & 912.46 & 52 & 912.43 & 52 \\
& 18 November 2016 & 900.85 & 52 & 916.84 & 53 & 900.87 & 52 \\
\hline
\end{tabular}

season, but the duration was higher than the Yala season for AGDD amount. Sesame is a quantitative short-day annual and it would be dried out 5 months after planting (Langham 2007; Suddihiyam et al. 1992). Plants that flowering is encouraged by that short-day condition, but they could be flowering even under long photoperiods are defined as quantitative short day plants (Hopkins and Huner 2008). During plant growth, many morphological differences have occurred at different growth stage from seed germination to the drying stage. The length of any growth stage is always not unique because duration would be affected by different genetics, agronomical and environmental factors (Hegde 2012; Weiss 2000; Mulkey et al. 1987). There are four major phases in sesame phenology up to the harvesting stage (Langham 2007; Attibayeba et al. 2010).

The drying phase is divided into three stages which are full maturity, initial dry-down and late dry-down. This phase is lengthening from physiological maturity until complete drydown (Langham et al. 2008). This phase also extending due to high moisture availability, high humidity, low temperature, and lesser sunshine and duration would be reduced by the opposite conditions (Langham 2007).

\section{Yield parameters of sesame}

The interaction effect between variety and the sowing date (V x SD) was not significantly different among treatments for the seed weight of the 15 plants in the Yala season. However, there was a significant difference among varieties $(\mathrm{P}<0.001$; Fig. 5A) and sowing dates $(\mathrm{P}<0.01$; Fig. 5B) for the seed yield of 15 plants. Var. Uma (37.03 g + 1.50) and Male $(34.79 \mathrm{~g}+2.12)$ recorded significantly high seed weight per 15 plants compared to MI-3 (24.52 g + 1.56). Early sowing date in the Yala season seems to have a positive effect on seed weight. Hence, the highest seed weight per 15 plants was

Table 6: Accumulated thermal time as growing degree days (AGDD) from seed sowing to $100 \%$ of the flowering of three varieties at three sowing dates in Yala and $\mathrm{Ma}$ $h a$ season. Time taken for reaching to the particular stage is given as number of days after seed sowing (DAS)

\begin{tabular}{cccrcrcr}
\hline \multirow{2}{*}{ Season } & Sowing date & \multicolumn{2}{c}{ Uma } & \multicolumn{2}{c}{ Malee } & \multicolumn{2}{c}{ MI-3 } \\
\cline { 2 - 7 } & & AGDD & DAS & AGDD & DAS & AGDD & DAS \\
\hline \multirow{3}{*}{ Yala } & 07 April 2016 & 1068.95 & 54 & 1107.65 & 56 & 1087.51 & 55 \\
& 21 April 2016 & 1072.97 & 54 & 1092.77 & 56 & 1092.77 & 56 \\
& 05 May 2016 & 1077.87 & 56 & 1097.72 & 57 & 1097.72 & 57 \\
\hline \multirow{3}{*}{ Maha } & 21 October 2016 & 1033.5 & 58 & 1069.31 & 60 & 1051.25 & 59 \\
& 04 November 2016 & 1031.85 & 59 & 1066.95 & 61 & 1049.25 & 60 \\
& 18 November 2016 & 1030.05 & 60 & 1078.73 & 63 & 1046.25 & 61 \\
\hline
\end{tabular}


Table 7: Accumulated thermal time as growing degree days (AGDD) from seed sowing to physiological maturity of three varieties at three sowing dates in Yala and $\mathrm{Ma}$ ha season. Time taken for reaching to the particular stage is given as number of days after seed sowing (DAS)

\begin{tabular}{cccrrrrr}
\hline \multirow{2}{*}{ Season } & \multirow{2}{*}{ Sowing Date } & \multicolumn{2}{c}{ Uma } & \multicolumn{2}{c}{ Malee } & \multicolumn{2}{c}{ MI-3 } \\
\cline { 2 - 7 } & & AGDD & DAS & AGDD & DAS & AGDD & DAS \\
\hline \multirow{3}{*}{ Yala } & 07 April 2016 & 1417.52 & 72 & 1668.87 & 82 & 1688.12 & 86 \\
& 21 April 2016 & 1423.22 & 73 & 1666.62 & 82 & 1686.92 & 86 \\
& 05 May 2016 & 1418.97 & 73 & 1668.07 & 83 & 1686.07 & 87 \\
\hline \multirow{3}{*}{ Maha } & 21 October 2016 & 1326.37 & 75 & 1451.86 & 83 & 1582.25 & 91 \\
& 04 November 016 & 1322.86 & 77 & 1456.42 & 85 & 1589.05 & 93 \\
& 18 November 2016 & 1328.85 & 78 & 1459.73 & 86 & 1583.05 & 93 \\
\hline
\end{tabular}

observed when seeds were sown on $7^{\text {th }}$ April $2016(37.01 \mathrm{~g}+2.21)$ than on 21st April 2016 $(31.02 \mathrm{~g}+2.62)$ or 5th May $2016(28.32 \mathrm{~g}+$ 1.90). In the Maha season, the interaction between variety and the sowing date $(\mathrm{P}<0.05)$ was significant for seed weight per 15 plants (Fig. 5C).
Seed dry weight per plot was significantly affected by the interaction between variety and the sowing date $(\mathrm{P}<0.01$; Fig. $6 \mathrm{~A})$ in the Yala season but not in the Maha season. However, the variety $(\mathrm{P}<0.001$; Fig. 6B) and the sowing date $(\mathrm{P}<0.001 ;$ Fig. $6 \mathrm{C})$

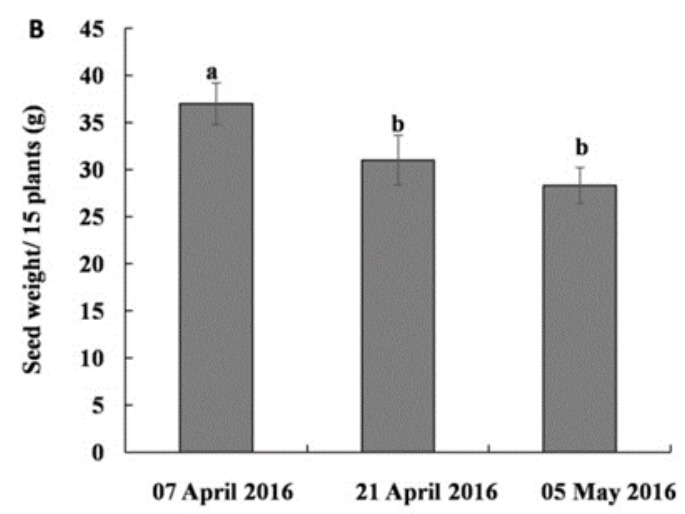

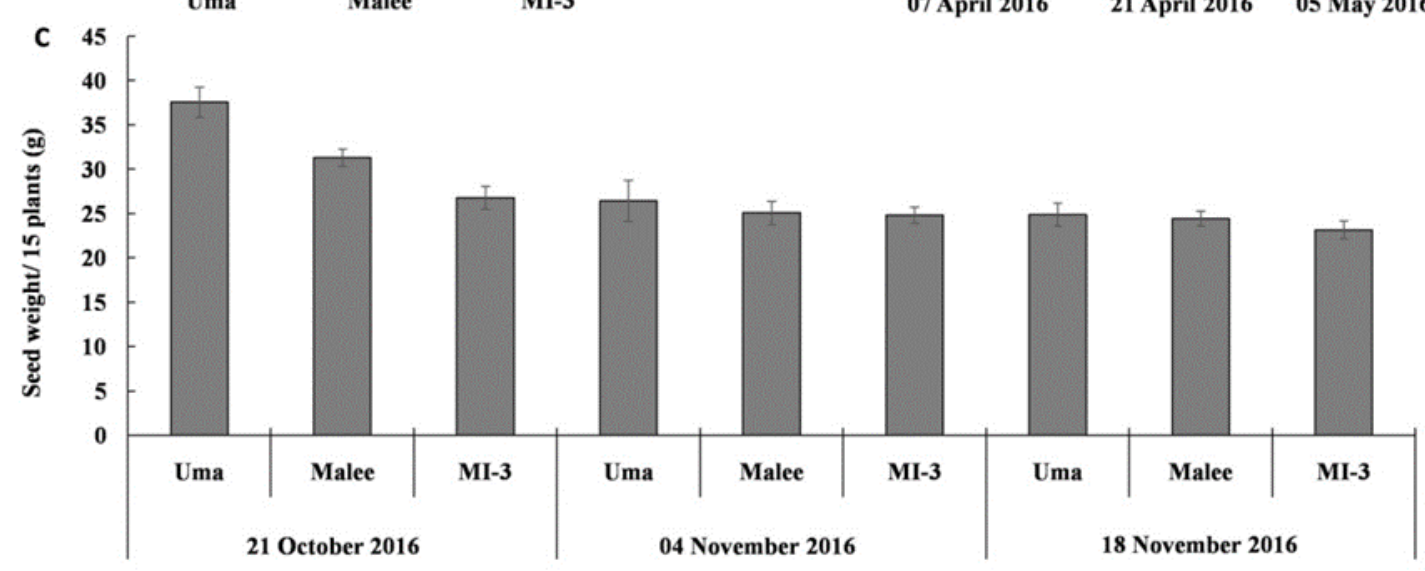

Figure 5: Seed dry weight of 15 plants as affected by (A) variety (B) sowing date in Yala season 2016 and $(C)$ interaction effect between variety and sowing date in Maha season 2016/2017. Ear bars indicate stand error of the means. Means with same letters are not significantly different at $\alpha=0.05$ as Duncan Multiple Range Test 

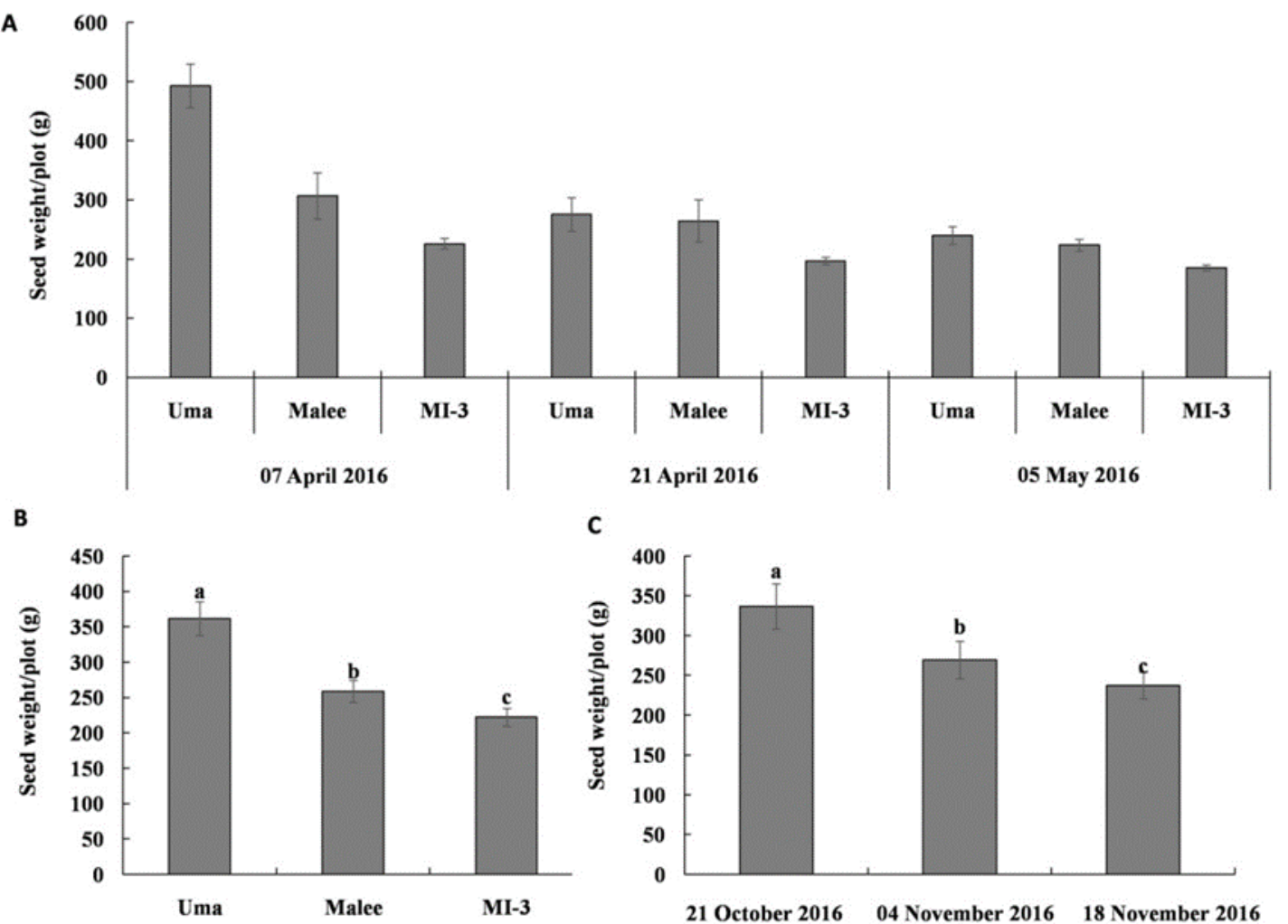

Figure 6: Seed dry weight per plot as affected by (A) interaction between variety and sowing date in Yala season 2016 (B) varietal effect on seed weight per plot and (C) effect of sowing date on seed weight per plot in Maha season 2016/2017. Ear bars indicate stand error of the means. Means with same letters are not significantly different at $\alpha=0.05$ as Duncan Multiple Range Test

significantly influenced the dry weight per plot in the Maha season. The highest seed weight per plot was recorded by variety var. Uma and the lowest weight by var. MI-3. When seeds sowed early in the season, the seed weight of the plot were high when compared to late sowing dates in the Maha season. The mean seed weight per plot was significantly different between the three sowing dates.

The interaction effect of variety and sowing date for 1000 seed weight was not significant in both seasons. However, the varietal effect on 1000 seed weight was significant in the Yala season $(\mathrm{P}<0.001$; Fig. $7 \mathrm{~A})$ while both variety $(\mathrm{P}<0.01$; Fig. $7 \mathrm{~B})$ and the sowing date $(\mathrm{P}<0.01$; Fig. 7C) significantly influenced the 1000 seed weight in the Maha season.

There was no interaction effect between variety and the sowing date for AGDD requirement and the number of days after sowing to reach into physiological maturity of the crop in both seasons. However, the variety $(\mathrm{P}<0.001)$ and the sowing date $(\mathrm{P}<0.001)$ had significant variation in both seasons. According to that, in both seasons, AGDD requirement of var. Uma to reach physiological maturity was significantly lower than the other two varieties. Hence, var. Uma needs fewer days from seed sowing to maturity. At the same time, var. MI-3 needed high AGDD and took approximately 14 more days to reach to maturity in both seasons. Vora et al. (2018), based on a two-year field study in India on heat requirement of short duration crops of sesame, black gram and pearl millet together with long duration crops of cotton, castor and groundnut found that the highest growing degree days, the highest efficiency of heat use and the highest yield for both types of crops recorded at early planting dates. It was suggested that the early sown 


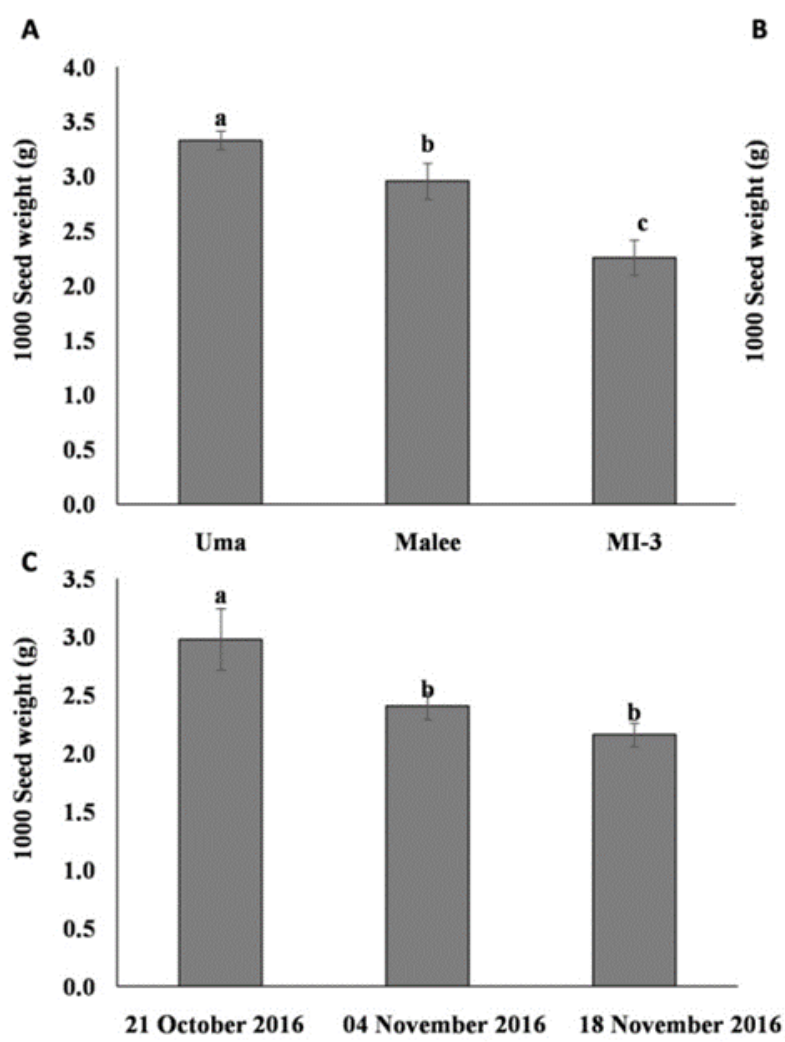

crops had higher utilization of thermal energy while delay in planting resulted in a decreased yield of short and long duration monsoon crops. Ali and Jan (2014) found that the early sowing date significantly lengthened the vegetative and reproductive phases, high vegetative growth and biological yield than the late sowing dates in Pakistan. According to the results of several studies, the early planting and mid-planting dates were more productive than later planting days for sesame. Further, the interaction between sowing dates and sesame genotypes was nonsignificant. It indicates that the productivity of sesame genotypes affect significantly as same as the sowing dates (Sawant et al. 2017; Sawant et al. 2019).

According to the results of the studies conducted in southeastern Nigeria found that the planting time had a significant effect on the growth and yield of sesame (Ogbonna and Umar-Shaba, 2012; Olowe, 2007) while the appropriate sowing time for sesame was during the later part of the rainy season. Furthermore, the plant height, number of leaves, stem circumference and the number of

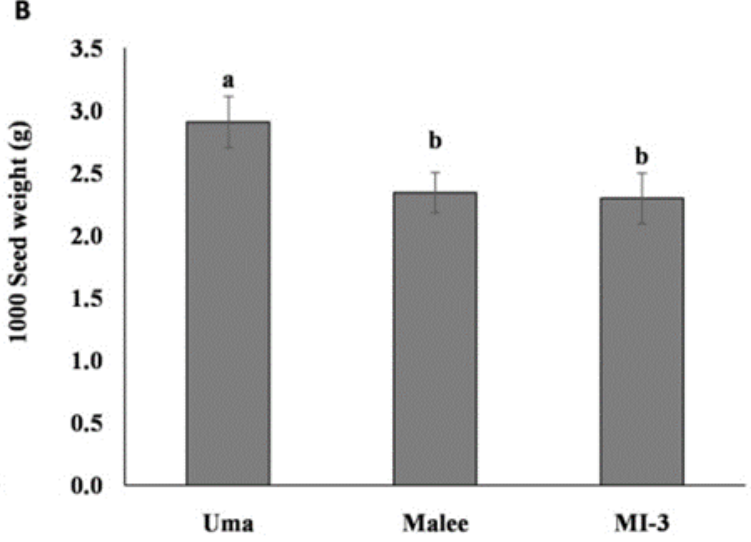

Figure 7: Dry weight of 1000 seeds as affected by (A) variety in Yala season in 2016 (B) variety in Mala season and (C) sowing date in Maha season 2016/2017. Ear bars indicate stand error of the means. Means with same letters are not significantly different at $\alpha=0.05$ as Duncan Multiple Range Test

branches per plant decreased due to the late planting (Ogbonna and Umar-Shaba, 2012). Sesame sown in early July grew faster and produced significantly higher weight of capsules and seeds per plant. It also produced more number of capsules per plant and higher seed weight (Olowe, 2007). Early planting in the season significantly increased grain yield for all accessions (Ogbonna and Umar-Shaba, 2012; Olowe, 2007). It is recommended to plant sesame in early July to middle of the month to achieve sustainable yield in Nigeria (Olowe, 2007). Among climatic factors, rainfall seems to contribute more to changes in yield throughout planting dates (Ogbonna and Umar-Shaba, 2012; Olowe, 2007). Another experiment conducted in northern Sudan with the aim of evaluating growth and yield of some promising sesame genotypes under different planting dates in mid-June, early July, and mid-July found that the planting dates was significantly affected on different growth and phenological parameters. Further, the highest seed yield was recorded when sowing was done in early July (ElMahdi, 2007). 


\section{CONCLUSION}

According to the results, measured plant growth parameters had significant relationships with AGDD. Therefore, received AGDD would be significantly affected the plant growth. Also, plant height and the number of leaves could be accurately predicted by using the fitted non-linear regression models for tested varieties for tested sowing dates. var. Uma cultivated at the early sowing date recorded the lowest AGDD to shift from one phonological phase to another. It showed the fastest growth and development than other varieties and sowing dates. Therefore, Uma was the best variety among tested due to its great adaptation ability and significantly high growth and development. Therefore, cultivating Uma, early in the Yala season would be the best combination based on growth. Var. MI-3 showed some adaptation to the Maha season than the Yala season with regards to growth. Accordingly, it seems that var. Uma sowing in the early of the season is the best combination for sesame cultivation in the dry zone of Sri Lanka in both seasons. However, it is difficult to recommend var. Uma as an efficient variety when sowing early in the season since a single data set for each season is not sufficient for field research to give a solid recommendation.

\section{AUTHOR CONTRIBUTION}

HWKPK performed the experiments, analysed \& interpreted data. WMNDG conceptualised \& designed the study. HWKPK, WMNDG and KMCF contributed in drafting the manuscript. $\mathrm{KMCF}$ critically revised the manuscript.

\section{REFERENCES}

Ahmad D, Kanth R and Parvaze S 2017 Growing Degree Days to Forecast Crop Stages. in Experimental Agrometeorology: A Practical Manual. Springer, Cham, pp. 95-98. doi: 10.1007/978-3-319-69185-5 14.

Ali S and Jan A 2014 Sowing dates and nitrogen level effect on yield and yield attributes of sesame cultivars, Sarhad Jounal of Agriculture, 30 (2): 203-209.

AgStat (2020). Socio-Economics and Planning Centre, Department of Agriculture, Peradeniya.

Anandhi A 2016 Growing degree days Ecosystem indicator for changing diurnal temperatures and their impact on corn growth stages in Kansa', Ecological Indicators, 61: 149-158. doi: 10.1016/j.ecolind.2015.08.023

Ashri A 1998 Sesame Breeding, In Janick, J. (ed.) Plant Breeding Reviews. John Wiley \& Sons, pp. 179-228. doi: https:// doi.org/10.1002/9780470650110.ch5.

Attibayéba, Elie NM, Sérina NJ, Dianga JGC and François MYE 2010 Description of different growth stages of Sesamum indicum L. using the extended $\mathrm{BBCH}$ scale. Pakistan Journal of Nutrition. 9 (3): 235-239. doi: 10.3923/ pjn.2010.235.239.

Bahrami H, Razmjoo J and Jafari AO 2012 Effect of drought stress on germination and seedling growth of sesame cultivars (Sesamum indicum L.). International Journal of AgriScience. 2 (5): 423-428.

Basu S, Parya M, Dutta SK, Jena S, Maji S, Nath R, Mazumdar D and Chakraborty PK 2012 Effect of growing degree day on different growth processes of wheat (Triticum aestivum L.), Journal of Crop and Weed, 8(2): 18-22.

Bekere L, Sile T, Bethers U and Sennikovs J 2015 Climate change impact on growing degree day accumulation values, Geophysical Research Abstracts, 17, p. 5446.

Danneberger, K., \& Cushnahan, M. (2014). Growing degree days. New Zealand Sport Turf Journal. Summer November, 12-13.

Dissanayake IAJK, Ranwala SMW and Perera SSN 2017 Agronomic status of Sesame / Thala (Sesamum indicum L .) cultivations in dry regions of Sri Lanka, International Journal of Agronomy and Agricultural Research, 11(1): 42-50. 
Dubey A, Verma S, Goswami SP and Devedee AK 2018 Effect of Temperature on Different Growth Stages and Physiological Process of Rice crop-As a Review, Bulletin of Environment, Pharmacology and Life Sciences, 7(11): 129-136.

Dutta A, Dutta SK, Jena S, Nath R, Bandyopadhyay $\mathrm{P}$ and Chakraborty PK 2011 Effect of growing degree days on biological growth indices of wheat and mustard. Journal of Crop and Weed, 7(1): 70-76.

El-Mahdi ARA, El-Amin SE and Ahmed FG 2007 Effect of sowing date on the performance of sesame (Sesamum indicum L .) genotypes under irrigation conditions in northern Sudan, African Crop Science Conference Proceedings Vol. 8. pp. 1943-1946

Gloaguen RM, Byrd S, Rowland DL, Langham DR and Couch A 2018 Planting date and row spacing effects on the agronomic potential of sesame in the southeastern USA. Journal of Crop Improvement. 32(3): 387-417. https://

doi.org/10.1080/15427528.2018.1434 093

Hassan QK, Bourque CPA, Meng FR and Richards W 2007 Spatial mapping of growing degree days: an application of MODIS-based surface temperatures and enhanced vegetation index, Journal of Applied Remote Sensing, 1 (1): 013511. doi: 10.1117/1.2740040.

Hatfield JL and Prueger JH 2015 Temperature extremes: Effect on plant growth and development, Weather and Climate Extremes, 10: 4-10. doi: https:// doi.org/10.1016/j.wace.2015.08.001.

Hegde DM 2012 Sesame in Handbook of Herbs and Spices: Second Edition, pp. 449-486.

doi: 10.1533/9780857095688.449.

Hopkins WG and H"uner NPA 2008 Measuring Time: Controlling Development by Photoperiod and Endogenous Clocks, in Introduction to plant physiology. 4th edn. John Wiley \& Sons, Inc., pp. 413-432.
Kumazaki T, Yamada Y, Karaya S, Tokumitsu T, Hirano T, Yasumoto S, Katsuta M and Michiyama H 2008 Effects of Day Length and Air Temperature on Stem Growth and Flowering in Sesame. Plant Production Science, 11(2), 178-183. doi:10.1626/ pps.11.178

Lalic B, Francia M, Eitzinger J, Podraščanin Z and Arsenić I 2016 Effectiveness of short-term numerical weather prediction in predicting growing degree days and meteorological conditions for apple scab appearance. Meteorological Applications, 23(1): 50-56. doi:10.1002/met.1521

Langham R 2007 Phenology of Sesame, in Janick, J. and Whipkey, A. (eds) New crops and new uses. Alexandria, VA: ASHS Press, pp. 144-182.

Langham DR, Riney J, Smith G and Wiemers T 2008 Sesame grower guide. Sesame Coordinators, San Antonio, TX.

Langham R 2016 Growth and development of sesame. American Sesame Growers Association.

Meena H and Rao A 2013 Growing degree days requirement of sesame (Sesamum indicum) in relation to growth and phonological development in Western Rajasthan, Current Advances in Agricultural Sciences, 5(1): 107-110.

Miller P, Lanier W and Brandt S 2001 Using Growing Degree Days to Predict Plant Stages, Montana State University Extension Service, 9, p. MT00103 AG 7/2001.

Mulkey JR, Drawe HJ and Elledge RE 1987 Planting Date Effects on Plant Growth and Development in Sesame, 703(21): 701-703.

Natural Resource Management Center (2003) 'Agro-Ecological Map of Sri Lanka'. Peradeniya: Department of Agriculture.

Ogbonna PE and Umar-Shaba YG 2012 Time of Sowing Affects the Growth and Yield of Sesame in a Derived Savanna Agroecology of Southeastern Nigeria. The Philipp Agric Scientist, 95(2):153-159. 
Olowe VIO 2007 Optimum Planting Date for Sesame (Sesamum indicum L.) in the Transition Zone of South West Nigeria, Agricultura Tropica et Subtropica, 40(4): 156-164.

Oplinger ES, Putnam DH, Kaminski AR, Hanson CV, Oelke EA, Schulte EE and Doll JD 1990 Sesame. In: Alternative field crops manual. Univ. of Wisconsin and Univ. of Minnesota Cooperative Extension. https:// hort.purdue.edu/newcrop/afcm/ mungbean.html

Pandey R and Paul V 2017 Plant growth analysis, Physiological Techniques to Analysis the Impact of Climatic Change on Crop Plants. New Delhi, India: Division of Plant Physiology, IARI, pp. 103-107. doi: 10.13140/ RG.2.2.21657.72808.

Paparrizos S and Matzarakis A 2017 Present and future assessment of growing degree days over selected Greek areas with different climate conditions, Meteorology and Atmospheric Physics, 129(5): 453-467. doi: 10.1007/s00703-016-0475-8.

Parthasarathi T, Velu G and Jeyakumar P 2013 Impact of Crop Heat Units on Growth and Developmental Physiology of Future Crop Production: A Review, Research \& Reviews : Journal of Crop Science and Technology, 2(1): 1- 11.

Sawant DM, Alse UN, Asewar BV and Khobragade AM 2017 Phenological studies on Sesamum (Sesamum indicum L.) varieties under varied weather condition, Journal of Agriculture Research and Technology, 42(3): 119-125.

Sawant DM, Alse UN, Asewar BV and Khobragade AM 2019 Correlation Studies between Weather Parameters and Sesamum (Sesamum indicum L.) Varieties Yield at Different Phenophases under Change in Climate, International Journal of Current Microbiology and Applied Sciences, 8(05): 997-1002. https:// doi.org/10.20546/ijcmas.2019.805.117
Suddihiyam P, Steer BT and Turner DW 1992 The Flowering of Sesame (Sesamum indicum L.) in Response to Temperature and Photoperiod, Australian Journal of Agricultural Research, 43(5), pp. 1101-1116. doi: 10.1071/ar9921101.

Vora VD, Sanepara DP, Chopada MC, Vekariya PD, Patel JT, Rakholiya KD, Sharma GR and Sutaria GS 2018 Thermal requirement of kharif crops under rainfed condition in north Saurashtra of Gujarat, Journal of Pharmacognosy and Phytochemistry, 7 (1): 666-670.

Weiss EA 2000 Oilseed crops. Oxford: Blackwell Science. ISBN 0-632-05259 $-7$

Yin Y, Deng $\mathrm{H}$ and $\mathrm{Wu}$ S 2019 Spatialtemporal variations in the thermal growing degree-days and season under climate warming in China during 1960 - 2011, International Journal of Biometeorology 63, 649-658. https:// doi.org/10.1007/s00484-017-1417-y 